\title{
Settling Disputes:
}

\section{A Matter of Politics and Law}

\author{
Nigel D. White ${ }^{*}$
}

\section{Introduction}

Intractable disputes are characterised by multi-layered accusations and counter-accusations and involve situations where history, politics and law conspire to render an already complicated situation impenetrable to weaker mechanisms of collective security. In addition, as a result of the various interests of the five permanent members of the Security Council, most such disputes are beyond the reach of Chapter VII of the UN Charter. Long running disputes, for example, between Israel and Palestine over the Occupied Territories, India and Pakistan over Kashmir, Cyprus and Turkey over Northern Cyprus, the US and Cuba over unremediated confiscations of US property following the seizure of power by Fidel Castro in 1959 and the subsequent imposition of an embargo by the US, US and Iran over the latter's nuclear ambitions, the sovereignty disputes over the Falklands/Malvinas between the UK and Argentina and over Gibraltar between the UK and Spain, remain unresolved and seemingly insoluble.

This chapter attempts to explore dispute settlement in this barren landscape where it seems that the politics of opposition, in which states not only oppose each other but, after a time, often oppose a solution to the dispute, outweigh the restoration of normal relations between states based on basic principles of international law. The chapter treads a precarious path between two extremes to dispute settlement, one based more-or-less on politics and one based on applying legal rules, neither of which provide evidence of success. At one end we have settlement by means of power politics in its various manifestations, which may or may not involve the use of measures authorised by the Security Council

\footnotetext{
*I would like to thank Marc Wesley and Lydia Davies-Bright for their research assistance on this chapter.
} 
under Chapter VII of the Charter, for example Iraq in 2003, ${ }^{1}$ Dayton in relation to Bosnia in $1995,{ }^{2}$ or Kosovo in $1999 .^{3}$ On the other, there is a formalist approach to settlement, which fails because it does not facilitate a process of the coming together of the disputant states seen, for example, in the approach of the European Community to the disintegration of Yugoslavia in the early 1990s, exemplified by the work of the Badinter Commission, even though its legal reasoning was suspect. ${ }^{4}$

The approach identified in this chapter allows for political settlement within a legal framework. It does this by arguing that the primary rules of international law can provide a framework for settlement and that the secondary rules on state responsibility should, within limits, facilitate the practicalities of dispute settlement. Rather than diminish the relevance of international law, it is demonstrated that there is potential for law to play a central role in helping the parties to create an agreed framework within which they can settle their dispute. This contrasts with a more orthodox approach to rule application when law is applied, in a determinant manner, in a method under which one side loses and the other wins. International law works best, in dispute settlement at least, when the focus is less on deciding on who wins and who loses and, rather, on offering a framework for states to decide on how to resolve their differences and the issues between them.

Even if a dispute does find its way to an authoritative judicial body, such as the International Court of Justice, there is little guarantee that the losing state will accept the judgment of the Court, especially in such a complex case as would be presented by the parties to any of the disputes mentioned thus far. If dispute settlement is to work in these circumstances, it is essential that alternative

\footnotetext{
${ }^{1} \mathrm{~J}$. Strawson, 'Provoking International Law: War and Regime Change in Iraq' in F. Johns, R. Joyce and S. Pahuja (eds), Events: The Force of International Law (Abingdon: Routledge, 2010), p. 247: 'the long reach of colonialism has bequeathed doctrinal ambiguities on the use of force, occupation and regime change, the key issues at stake over Iraq'.

${ }^{2}$ See, for example, R. Caplan, 'International Authority and State Building: The Case of Bosnia and Herzegovina', Global Governance, 10 (2004), 53 at 58: 'can change that will allow Bosnia to function as a self-sustaining liberal democratic state be achieved ultimately by means of administrative fiat?'; F. Ni Aolain, 'The Fractured Sole of the Dayton Peace Agreement: A Legal Analysis', Michigan Journal of International Law, 18 (1998), 957 at 971 : 'this is a Dayton constitution not a Bosnia constitution'.

3 J. Alvarez, 'Hegemonic International Law Revisited', American Journal of International Law, 97 (2003), 873: 'few appear terribly concerned about the prospect of hegemonic rule through the collective processes of international law, including the Security Council'.

${ }^{4}$ P. Radan, 'Post-Secession International Borders: A Critical Analysis of the Opinions of the Badinter Arbitration Commission', Melbourne University Law Review, 24 (2000), 50 at 74: 'To insist, in cases of secession from a federal state, that internal federal borders automatically should become international borders is to establish the Badinter Borders Principle as a new rule of international law. On the analysis of the legal reasoning adopted by the Badinter Commission in Opinion No 3 this rule has no principled foundation in international law. More fundamentally, irrespective of whether this new rule of international law is or is not soundly based in international law, it is, in political and practical terms, too simplistic and inflexible as is amply illustrated in the case of the fragmentation of the SFRY'.
} 
understandings of the principles of international law, ${ }^{5}$ as well as alternative mechanisms for dispute settlement, are considered by the parties, if agreement is to be achieved. There is no magic formula that will solve the dispute and, it is submitted, that it is a mistake to consider that international law works in such a manner.

This chapter places dispute settlement broadly within Martii Koskenniemi's indeterminacy thesis, and then adapts his idea of international law as the 'gentle civilizer of nations', which he posited generally in the form of a question: 'between the arrogance of universality and the indifferences of particularity, what else is there apart from the civilized manner of gentle spirits?'. ${ }^{6}$ After outlining Koskenniemi's analysis of how law can play a role in relation to collective security, this chapter applies such thinking to bilateral disputes. In so doing, it shows that such disputes are not resolved by the indifferences of particularity' but, drawing on Koskenniemi's idea, it argues that when the political regime encasing the dispute collapses, or radically changes, law can play a crucial role in establishing a new political regime based on the normalisation of relations.

Such a normalisation of relations is not only based on applicable principles of international law, but also on underpinning values of peace, justice and reconciliation. These values find current expression, for example, within modern ideas of transitional justice, a regime that has emerged most strongly within the context of post-conflict rebuilding. Transitional justice is based on the premise that without both a reckoning (as regards past abuses) as well as a reconciliation (between groups and individuals on different sides of the conflict), the underlying cycle of violence will only be broken temporarily. Clearly, there is a tension between reckoning and reconciliation so that often a peace process contains forms of compromise between the two, such as conditioned amnesties and alternative forms of accountability. ${ }^{7}$ Thus, in bilateral disputes, characterised by regular outbreaks of armed conflict (over Kashmir in 1949, 1965 and 1971; in the Middle East, principally in 1948, 1956, 1967 and 1973; against Cuba in the Bay of Pigs in 1961; over Cyprus with the Turkish intervention in 1974; and over the Falklands/Malvinas in 1982), the levels of hostility between the two countries have been such that, before normal relations can be established, a post-dispute (or post-confrontation) phase has to be navigated by the parties. Transitional justice and related arguments for a jus post bellum, ${ }^{8}$ although

\footnotetext{
${ }^{5}$ S. Allen and E. Guntrip, 'The Kosovo Question and Uti Possidetis: The Potential for a Negotiated Solution' in J. Summers (ed), Kosovo: A Precedent? (Leiden: Nijhoff, 2011), p. 303 at p. 315.

${ }^{6}$ M. Koskenniemi, The Gentle Civilizer of Nations: The Rise and Fall of International Law (Cambridge University Press, 2002), p. 515.

${ }^{7}$ A-M. La Rosa and X. Phillipe, 'Transitional Justice' in V. Chetail (ed), Post-Conflict Peacebuilding: A Lexicon (Oxford University Press, 2009), p. 368.

${ }^{8}$ C. Stahn, J.E. Esterday and J. Iverson (eds), Jus Post Bellum: Mapping the Normative Foundations (Oxford University Press, 2014), p. 5: 'it is still unclear whether jus post bellum is a construct, a strand of research, or a sub-discipline of existing paradigms'.
} 
not directly applicable to disputes between states, serve to illustrate that international law has the potential to facilitate a dynamic environment in which both peace and justice can be built. Furthermore, the chapter demonstrates that the values most prominently found in transitional justice are also actually located, but buried more deeply, in the more orthodox and traditional methods of dispute settlement between states.

The chapter is structured as follows: first it considers the place of law in the politics of settlement, drawing on Martii Koskenniemi's analysis of the indeterminacy of international law, and how, despite that, international law still has relevance, not only as a 'gentle civilizer' in times of relative stability, but as an important form of stability in times of change. The chapter then moves on to consider how this applies within a bilateral dispute where the principles of reciprocity and restoration, which are shown to be interlaced in the structures of international law, help to ensure that the bilateral situation moves from the politics of confrontation, towards the politics of normalisation; in other words, from a situation that violates international law and threatens international relations, towards one that is in conformity with international law and restores a condition of peaceful co-existence between states. The chapter also considers how diplomacy can lead to finding common legal ground, enabling the parties to achieve relative certainty within a system of primary and secondary rules of international law characterised by indeterminacy. The chapter goes on to demonstrate that this understanding of international law is compatible with traditional political (non-judicial) methods of dispute settlement, which are based on reciprocity and restoration, and that it is helpful, but not necessary, to use analogies with transitional justice to make this point.

\section{Place of law in the politics of settlement}

Law, at any level, whether national, regional or international, is a product of politics, but law is also expected to provide a normative framework within which political discretion should be exercised so that the political system is subject to the rule of law. In international relations, however, given the continuing dominance of sovereign states, it is more difficult to maintain that there exists an international rule of law, despite UN rhetoric to that effect. ${ }^{9}$ The deeper reason for this is clearly exposed by the critical methodology of Martti Koskenniemi, who wrote in 1990, against the backdrop

\footnotetext{
${ }^{9}$ See, for example, UN Doc A/RES/68/116 (2013): 'The rule of law at the national and international levels', which, at para 4, 'reaffirms the imperative of upholding and promoting the rule of law at the international level in accordance with the principles of the Charter of the United Nations'.
} 
of a claimed new world order emerging in the radically changed circumstances at the end of the Cold War, that:

Our inherited ideal of a World Order based on the Rule of Law thinly hides from sight the fact that social conflict must still be solved by political means and that even though there may exist a common legal rhetoric among international lawyers, that rhetoric must, for reasons internal to the ideal itself, rely on essentially contested - political - principles to justify outcomes to international disputes. ${ }^{10}$

The internal problem faced by international law is that the law, especially custom, is generated by state practice and so can be seen either as an excuse or an apology for state behaviour. Any attempt to depart from state practice can be dismissed as utopian and, therefore, irrelevant in that it will have no impact upon state behaviour. In order to achieve universal agreements in more formal documents, treaties or resolutions, norms are crafted in abstract and indeterminate terms. Thus, in these conditions:

Behind ritualistic references to well-known rules and principles of international law (the content of which remains a constant object of dispute), legal practice has increasingly resorted to resolving disputes by a contextual criterion - an effort towards an equitable balance. Though this has seemed to work well, the question arises as to whether such practice can be adequately explained in terms of the Rule of Law. ${ }^{11}$

In this way, law forms part of the debate and discussion within which disputes can be resolved but, in the end, abstract, disputed and often indeterminate universal rules can only provide guides towards an equitable solution that is politically just. ${ }^{12}$ The growth, since 1990 , of specialist international legal regimes, with greater precision in terms of rules, does not remove political choices, ${ }^{13}$ given that disputes refuse to neatly fit within only one legal regime. The US-Cuba dispute, for instance, involves issues of forcible and non-forcible measures, sovereignty and self-determination, democratic and socio-economic rights, as well as trade and investment. Resort to human rights norms and mechanisms will produce a different range of answers to ones sought within a trade regime. The problem is exacerbated when the disputants' participation in different regimes does not overlap significantly or even marginally (for example, by not being parties to the same multilateral treaties).

Furthermore, despite problems with indeterminacy, Koskenniemi argues that international laws, can, especially at certain crucial points, have a significant role to play, even within highly politicised regimes

\footnotetext{
${ }^{10}$ M. Koskenniemi, 'The Politics of International Law', European Journal of International Law, 1 (1990), 4 at 7.

11 Ibid., 14.

12 Ibid., 31.

${ }^{13}$ M. Koskenniemi, 'The Politics of International Law - 20 Years Later', European Journal of International Law, 20 (2010), 7 at 11.
} 
concerning the security of states. In contrast, realism foresees security being achieved in such circumstances by states acting out of self-interest and, eventually, by achieving a balance of power. ${ }^{14}$ Koskenniemi argues that a pure realist approach still contains within its method normative premises involving stylised and abstract understandings of concepts, such as 'interest' (as in the national 'interest'), 'security' (as in national 'security') and 'power' (as in balance of 'power'). In addition, he argues that the legal justifications invariably put forward by states for their actions, under a balance of power or similar system, are not simply excuses but meaningful justifications and explanations for action. ${ }^{15}$ In effect, it could be argued that to act both out of self-interest and within the constraints of the law are not mutually exclusive actions given that law influences how self-interest can be pursued.

According to Koskenniemi, when the political context is stable, as it largely was during the superpower confrontation of the Cold War (at least after the period of decolonisation), law primarily plays a limited role, for example, in helping shape the text of Security Council resolutions to broadly conform with the UN Charter, as well as providing states with justifications for their political actions. ${ }^{16}$ Politics are, in effect, poured into a variety of legal vessels (treaties, resolutions and soft laws). However, when the political context radically changes and becomes unstable, the Charter and international law, more generally, take on a central role in shaping the boundary between law and politics. In these circumstances, international law acts as a constraint on discretion, not in a fully 'constitutional' sense, ${ }^{17}$ rather in a 'political' sense. International law performs the function of being a container within which politics are confined. This signifies that within a new political context, international law provides the parameters for political action, but international law is not a strong or, indeed, a rigid enough framework to fully constrain political considerations. In these conditions, the legal framework is significantly expanded and developed by interpretation and subsequent practice. ${ }^{18}$

In this way, at the end of the Cold War, international law was reinterpreted to apply to new circumstances, for example, in the Badinter Commission's interpretations of self-determination in the context of the break-up of Yugoslavia in the early 1990s. ${ }^{19}$ Faced with the break-up of a federal state, the Commission, established by the European Community, extended the idea of external self-

\footnotetext{
${ }^{14}$ J.J. Mearsheimer, 'Back to the Future: Instability in Europe after the Cold War' in M.E. Brown, O.R. Cote, S.M. Lynn-Jones and S.E. Miller (eds), Theories of Law and Peace (Boston: MIT Press, 1998), p. 3.

${ }^{15}$ M. Koskenniemi, 'The Place of Law in Collective Security', Michigan Journal of International Law, 17 (1996), 455 at $465,469,472,476$.

${ }^{16} \mathrm{Ibid}$., 473. See further, R. Higgins, 'The Place of International Law in the Settlement of Disputes by the UN Security Council', American Journal of International Law, 63 (1970), 1 at 4.

${ }^{17}$ Koskenniemi, 'The Place of Law in Collective Security', 478, 480.

${ }^{18}$ Subsequent practice is recognised as a means of interpretation in Article 31(3)(2)(b), Vienna Convention on the Law of Treaties 1969.

${ }^{19}$ See M. Craven, 'The European Community Arbitration Commission on Yugoslavia', British Yearbook of International Law, 66 (1995), 333.
} 
determination, which in the Cold War period occurred in relation to colonial territories, so as to cover new states emerging from the federal units within a collapsing Communist state. Essentially, decolonisation (arguably another period of instability in the 1950s and 1960s) was given normative form by the General Assembly's Declaration on Decolonisation of $1960,{ }^{20}$ which contained a principle of international law on external self-determination within colonial boundaries, and it was this norm that was adapted in the post-Cold War era to another sort of boundary within collapsing communist states.

According to Martii Koskenniemi, law also took on a shaping role in the 1990 crisis that followed the Iraqi invasion of Kuwait. The end of the Cold War meant that:

The traditional patterns of Council decision making had become irrelevant and inapplicable. There was no anterior political agreement, no longstanding negotiation with fixed positions, and no routine language to cover events. The situation was canvassed nowhere but in the Charter itself. As the debate took on a legal style and an engaged aspect, the rest of formalism followed suit. ${ }^{21}$

This took place, for example, in the search for legal precedent in the management of sanctions, in which the comprehensive regime against white Rhodesia from 1965 to 1979 was clearly the template, while the mandating resolution for force in 1950 against North Korea was used as the template for Resolution 678 (1990), which authorised member states to enforce the Security Council's demand for Iraqi withdrawal from Kuwait and 'to restore international peace and security to the area'.

The move to law was evidenced in the way these precedents were put together with other legally based responses, including declaring Iraq's annexation of Kuwait as null and void, in a suite of resolutions whereby the Council used its full range of Chapter VII powers in a unique way in 1990, but one in accordance with the UN Charter of 1945. It started with a determination of a breach of the peace under Article 39 and a demand for Iraqi withdrawal under Article 40 (in Resolution 660), then the Security Council successively imposed comprehensive sanctions against Iraq under Article 41 (Resolution 661), determined that Iraq's annexation of Kuwait was null and void (Resolution 662), authorised naval forces to enforce sanctions in a limited application of Article 42 (Resolution 665) and then it authorised full-scale force to remove Iraq (Resolution 678), with many fine-tuning resolutions in between. The war was brought to an end by a unique Resolution (687 of 1991), which imposed severe conditions upon Iraq, including supervised disarmament and a mechanism for providing compensation to victims of its aggression. Resolution 687 illustrates the malleability of international

\footnotetext{
${ }^{20}$ UN Doc A/RES/1514 (1960), Declaration on the Granting of Independence to Colonial Countries and Peoples.

${ }^{21}$ Koskenniemi, 'The Place of Law in Collective Security', 476-7.
} 
law in changed political conditions, but this does not mean that the Resolution was ultra vires, for if the Security Council is empowered to authorise the waging of war on a state it is equally empowered to bring it to an end.

The consensus between the five permanent members enabled the Council to develop a legal framework for its post-Cold War actions (implicitly acting under Charter Article 41's open-ended list of non-forcible measures) that would have been unimaginable during the Cold War. In addition to imposing post-war conditions upon Iraq, this enabled it to create international criminal tribunals for Yugoslavia and Rwanda and post-conflict administrations for Kosovo and East Timor. However, that consensus had dissipated by 2003 , with the US and the UK, bridling against Iraq's perceived lack of compliance, especially with the disarmament provisions of Resolution 687 (1991), taking unilateral military measures culminating in the full-scale invasion of Iraq in 2003.

In 2003 law once again took a back seat to politics, evidenced by the unconvincing attempts by the UK, in particular, to justify the use of force against Iraq on the basis that Resolution 678 of 1990 was somehow still a legally valid authorisation to use force. The 'revival' argument, as it came to be known, only came to the fore once it became clear that a follow-up resolution, one that would have allowed for the enforcement of the WMD inspection regime re-established by Resolution 1441 (2002), was not going to be achieved due to French and Russian reticence. ${ }^{22}$ Law was used instrumentally within the political context that became established after 9/11 in 2001.

After the terrorist attacks on New York and Washington of 11 September 2001, in which the world's remaining superpower was significantly wounded by a relatively small non-state terrorist group, the political context changed to a 'war on terror' or, more accurately, an age of terror. Arguably, international law, this time on self-defence, provided a constraint on US reaction within this new political context, but at the same time self-defence was adapted to a new form of threat. However, even after the new self-defence paradigm seemingly became accepted following $9 / 11$, the expansion of the right suffered from abuse in that it was used as a justification for a continuing war of selfdefence against terrorism, specifically al-Qaida, from 2001 to the present day. From receiving broad support for its initial use of force against Afghanistan in October 2001, US actions changed from those of a lawman to potentially those of a badman, due to its ill-considered prosecution of an unending defensive global war on terror.

\footnotetext{
${ }^{22}$ See Parliamentary Written Answer to House of Lords given by the Attorney General Lord Goldsmith, Hansard HL, Vol 646, WA2-3, 17 March 2003.
} 
Realism, relying on a "clear differentiation between legal "rules" and "political" interests and on the priority of the latter over the former', ${ }^{23}$ challenges the claim that international law has any traction in any of these instances, irrespective of changes in political context. Indeed, realists would point to the fact that powerful states' behaviour in 1990, 2001 and 2003 was unaffected by weak rules of international law. Furthermore, by recognising the indeterminacy of international law, and the primacy of politics, does the approach advocated by Koskenniemi itself open the door to realism? Michael Glennon argues that realism (what he terms 'pragmatism') provides a better explanation and approach to international law. For Glennon, realists 'believe that what ostensibly are background considerations inevitably affect legalist decision making; that reliance upon formal legal categories masks the decision-making process that actually occurs, which is situationally contingent' ${ }^{24}$ Glennon points out that not only are the formal rules largely irrelevant to state behaviour, especially in the areas of high politics concerning security and other national interests, but that, furthermore, there are no foundational principles upon which a legal order can be constructed. ${ }^{25}$ He rejects any notion of a moral basis for action, any concept of hierarchy in international law embodied in notions of jus cogens, as well as any purportedly abstract concepts such as 'community' or 'justice' ${ }^{26}$ Realists reject the 'paper rules' found in the Charter and in other treaties and in the distillation of custom by positivist international lawyers or judges, in favour of the 'working rules' that are observable empirically and do actually work in terms of inducing compliance. ${ }^{27}$

While superficially attractive because it is premised on the primacy of politics, realism effectively collapses any distinction between law and politics, between breach and compliance. Law is not simply an externally observable explanation of behaviour, but has an internal or argumentative aspect, evidenced by the use of normative language. ${ }^{28}$ For example, while the UN failed to agree on action against Iraq in 2003, a realist analysis of the 'real' rules would describe the policies and actions of those that wanted to use force. A realist analysis will usually shed light on the complexities of politics and power that go into decision-making processes, but this does not reveal the law, at least if we ascribe any autonomous function to the 'law'. The real 'rules' of realism are not rules at all but are wholly contingent explanations of behaviour, what Koskenniemi labels the indifferences of particularity'. ${ }^{29}$ The fact that the US used force in Iraq in 2003 out of self-interest and perceptions of

\footnotetext{
${ }^{23}$ Koskenniemi, 'The Place of Law in Collective Security', 463.

${ }^{24}$ M.J. Glennon, The Fog of Law: Pragmatism, Security, and International Law (Chicago: Stanford University Press, 2010), p. 3.

25 Ibid., p. 5.

26 Ibid.

27 Ibid., p.27.

${ }^{28}$ H.L.A. Hart, The Concept of Law, $3^{\text {rd }}$ edn (Oxford: Clarendon, 2012), pp. 89-91.

${ }^{29}$ Koskenniemi, The Gentle Civilizer of Nations, p. 515.
} 
threats to its security (and out of a sense of a job unfinished in 1991 and a vague idea that 9/11 and Iraq were related), and not out of a belief in the revival argument as a valid exception to the ban on the use of force, is not a 'rule' in any sense other than that any act of unpunished violence creates an argument that can be wielded against those that insist on a formal application of the law. According to Martii Koskenniemi, arguing that 'normative factors are either irrelevant or only marginally relevant ... undermines the degree to which any social action, including international activity, makes constant reference to normative codes, rules, or principles'. ${ }^{30}$ Furthermore, 'political events are never simply physical acts or people behaving empirically in this way or that', rather they 'exist in relation to a shared normative code of meaning'. ${ }^{31}$

The only rules that emerge from a realist analysis are those as defined by the realist - that power and self-interest explain action. In effect, such an approach replaces one set of foundations (based on jus cogens and other basic principles and purposes of international law) with normative foundations of another kind based on power and self-interest. Real rules are so contingent as to be impossible to formulate in any meaningful sense, resulting in a case-by-case analysis where any lessons learned cannot be put forward as universal rules. Legal principles may be weak in comparison to this reality, but the formal laws remain as constraints, no matter how weak, on power. To conflate power and law is to remove law from having any independent function from power including, arguably, its key function - as a restraint on power.

It may well be very difficult to prove that most states do not use force because of a formal legal principle prohibiting force in the UN Charter, ${ }^{32}$ but constant restatement of that principle by organs of the international community, such as the General Assembly, must indicate that the legal principle, despite problems with indeterminacy, is and will be a factor that helps shape state behaviour. Furthermore, Koskenniemi makes the point that 'Realism's causal modes were dependent upon, or could not be applied in abstraction from, normative choices regarding desirable courses of action' ${ }^{33}$ The alleged failure of the Security Council to fully adapt to the changed conditions of Iraq in 2003 does not mean that it has been irrelevant since its creation in 1945 when geopolitics were very different. ${ }^{34}$ The Council did adapt in 1990. Besides which, it is equally plausible to argue that the Security Council's inability to authorise force in 2003 was because the weight of world opinion was behind the threatened vetoes of France and Russia and not behind the warlike intentions of the US and the UK.

\footnotetext{
${ }^{30}$ Koskenniemi, 'The Place of Law in Collective Security', 468.

${ }^{31}$ Ibid.

32 Glennon, The Fog of Law, p. 89.

${ }^{33}$ Koskenniemi, 'The Place of Law in Collective Security', 471.

${ }^{34}$ But see Glennon, The Fog of Law, p. 163: 'the world today is saddled with the outmoded institutions of a bygone era'.
} 
In other words, the Council, by its inability to authorise force, reflected contemporary thinking on the rules governing when force should be used, meaning that the use of force by the US and the UK was not somehow lawful, but was what most believe it to be - an illegal use of force.

The invasion of Iraq 2003 can be analysed convincingly in terms of law's survival and continued independence from politics; but the fact remains (and this is the ultimate realist argument) that the US and UK got away with it, at least in the short-term. In response to this one can point to the problems both countries had in imposing their will on Iraq after the invasion, despite having Security Council approval for their occupation and state building (itself a legal contradiction since the law of occupation is antithetical to statebuilding). ${ }^{35}$ That initial intervention, in breach of the jus ad bellum, undermined the justice of their cause when trying to rebuild Iraq.

In fact, even during the Cold War the General Assembly played an important role as the conscience of the world community, regularly condemning superpower breaches of international law - for example, by the Soviet Union for its invasions of Hungary in 1956 and Afghanistan in 1979; ${ }^{36}$ the US for its hemispheric interventions, for example, in Grenada in 1983 and Panama in 1989; ${ }^{37}$ and, in the postCold War era, the punitive and vindictive US embargo of Cuba. ${ }^{38}$ Koskenniemi describes the Assembly as a temple of justice and warns against the Security Council taking on the mantle of justice, as this would lead to the police entering the temple. ${ }^{39}$ Unfortunately, this has not prevented the Security Council from deciding on issues of justice, or at least setting up mechanisms to deliver justice, for example, the ad hoc criminal tribunals in Rwanda and Yugoslavia. ${ }^{40}$ The Assembly, in contrast, has recently rediscovered its voice as the world slides once again towards great power confrontation following Russian intervention in Ukraine in 2014. The Assembly called upon states to 'desist and refrain from action aimed at the partial or total disruption of the national unity and territorial integrity of Ukraine, including any attempts to modify Ukraine's borders through the threat or use of force or other unlawful means' ${ }^{41}$

What the above analysis shows is that law plays a role in the most hostile of environments concerning collective and national security, where achieving agreement to take collective action against threats to the peace is extremely difficult, even more so when seeking to achieve agreement and take action

\footnotetext{
35 UN Doc S/RES/1483 (2003).

${ }^{36}$ UN Doc A/RES/1004 (1956); UN Doc A/RES/ES-6/2 (1980).

37 UN Doc A/RES/38/7 (1983); UN Doc A/RES/44/240 (1989).

${ }^{38}$ See, for example, UN Doc A/RES/67/4 (2012).

${ }^{39}$ M. Koskenniemi, 'The Police in the Temple Order, Justice and the UN: A Dialectical View', European Journal of International Law, 6 (1995), 325.

40 UN Doc S/RES/827 (1993); UN Doc S/RES/955 (1994).

${ }^{41}$ UN Doc A/RES/68/262 (2014) adopted by 100-11 with 58 abstentions.
} 
within the parameters of international law. It is largely true, as argued by Koskenniemi, ${ }^{42}$ that in periods of political stability, law is instrumental, but this perhaps misleads us into thinking that law has no controlling function. The fact that politics, to have longer-term relevance, have to be activated through legal instruments adopted in accordance with the UN Charter and broader principles of international law is a constraint, albeit a limited one. Moreover, as argued by Koskenniemi, in times of dramatic political change and instability, international law serves a much more central function in stabilising international relations and in framing diplomacy, settlement and more coercive measures.

The period following the invasion of Iraq in 2003 raises the question of whether, in general terms, international law has settled back into being a handmaiden to politics in issues of security, or whether it plays an external role to politics, challenging and perhaps controlling politics, despite it being, in a sense, inside social practices. Within bilateral disputes, we are confronted with an additional layer of politics, namely that governing the relations between the two states, in addition to the broader political context pervading in international relations. In these conditions, law may be expected to have reduced prospects as a means for settling disputes. Indeed, we might expect the particularities of the dispute to push out the generalities of international law. Bearing in mind Koskenniemi's warning against viewing the weaknesses of international law's claims to universality as an argument for simply dealing with particularities, it is contended that his analysis does apply to bilateral disputes so that law, despite its indeterminacy and its general subservience to politics, has relevance. In doing this we are not guilty of reducing international law to particularities, rather we are making the claim that it is, in one sense, easier to make the universalities of international law work within a bilateral context than it is within a collective context where the achievement of inter-subjective agreement is more difficult. ${ }^{43}$ This has to be balanced against the fact that in long-running bilateral disputes the levels of disagreement can go much deeper than at the multilateral level.

It follows that for international law to take on a significant shaping role in any process of dispute settlement, there must be a significant break in the prevailing political context. The end of the Cold War created new conditions enabling the revitalisation of existing (and seemingly exhausted) principles of law, such as self-determination in the context of the former Yugoslav and Soviet Republics, and self-defence in the context of the terrorist attacks of 9/11. In addition, this period saw further innovations in collective measures against international crimes (for example, the international

\footnotetext{
${ }^{42}$ Koskenniemi, 'The Place of Law in Collective Security', 473, 478, 480.

${ }^{43}$ On achieving inter-subjective agreements see I. Johnstone, 'Legislation and Adjudication in the UN Security Council: Bringing Down the Deliberative Deficit', American Journal of International Law, 102 (2008), 275. See also J. Habermas, Between Facts and Norms: Contributions to a Discourse Theory of Law and Democracy (Oxford: Polity, 1996), p. 107, where Habermas writes 'just those action norms are valid to which all possible affected persons could agree as participants in rational discourses'.
} 
criminal tribunals for the former Yugoslavia and Rwanda), ${ }^{44}$ and terrorism (for example, Security Council 'legislation' prohibiting support for terrorism). ${ }^{45}$ Arguably, the end of the Cold War should have been the context-breaking event that led to the end of a number of intractable bilateral disputes, for example, the US-Cuban confrontation, given the removal of Soviet support for Cuba and the opening of the Cuban economy to wider trade. However, the US decision was to continue the same political framework and, indeed, to re-enforce it by tightening the embargo in order to remove one of the few remaining Communist regimes. ${ }^{46}$ In effect, in 1991 the Cold War had ended between the superpowers but continued across the Florida Straits. However, it is contended that in bilateral disputes, while the broader international political conditions remain a factor, of more importance is the political relationship between the two states - if this sees a fundamental shift, then international law can operate to stabilise and normalise the relationship.

\section{Bilateral Disputes: Seeking agreement based on reciprocity and restoration}

As has been argued, in many bilateral disputes there are instances of uses of force between the states concerned and, although a condition of war may have been relatively brief, the dispute has been one of confrontation or conflict in a broad sense and could not be said to be a state of peace, so that there is a clear need for a process that leads to a peace agreement. In the reality of dispute settlement and negotiation of peace agreements, international norms jockey for influence within a politically unstable context. Indeed, peace agreements in the post-Cold War period have shown a number of similarities to the extent that it has been argued by Christine Bell that what is emerging is a form of lex pacificatoriae. ${ }^{47}$ Although most of these agreements are aimed at bringing an end to intra-state conflicts, those common principles identified by Bell are, in the main, also applicable to inter-state disputes.

Common features of peace accords include agreement by the parties on methods of achieving peace and security, self-determination and human rights, transitional justice (to address wrongful acts committed), and on the provision of access to justice. Without such an agreement covering peace and justice between the two disputant states, the cycle of confrontation and conflict will not be broken.

\footnotetext{
${ }^{44}$ UN Doc S/RES/827 (1993); UN Doc S/RES/955 (1994).

${ }^{45}$ UN Doc S/RES/1373 (2001).

${ }^{46}$ By means of the Torricelli Act 1992 and the Helms-Burton Act 1996. For discussion see P.J. Haney and W. Vanderbush, The Cuban Embargo: The Domestic Politics of an American Foreign Policy (Pittsburgh: University of Pittsburgh, 2005), pp. 86-9, 104-7.

${ }^{47}$ C. Bell, 'Peace Agreements: Their Nature and Legal Status', American Journal of International Law, 100 (2006), 373 at 373-5.
} 
Restoration of international relations takes precedence over retribution by means of punishment for wrongdoing, although the latter will normally have to be addressed. ${ }^{48}$

In addition to the primary rules of international law that are applicable to dispute settlement and peace agreements, the secondary rules of international law on state responsibility are also firmly grounded in securing the restoration of normal relations between states once they have been disrupted by internationally wrongful acts. Responsibility, in international law, is neither clearly delictual nor criminal, rather it is reflection of the very different legal and political order applying between states in international relations. It is worth noting in this regard that the criminalisation of certain aspects of state behaviour was not the route taken by the International Law Commission (ILC) in its drafting of the Articles on the Responsibility of States for Internationally Wrongful Acts in $2001 .{ }^{49}$ Whether or not the concept of state crimes persists, it is true to say that the law on state responsibility is not primarily concerned with punishing sovereign states for their wrongdoing, but on restoring peaceful and normal relations between them. Although the rules on state responsibility seem rather abstract and formal, it will be shown that they operate within what Koskenniemi calls a 'culture of formalism' that 'builds on formal arguments that are available to all under conditions of equality'. ${ }^{50}$ The 'culture of formalism':

Seeks to persuade the protagonists (lawyers, decision-makers) to take a momentary distance from their preferences and to enter a terrain where these preferences should be justified, instead of taken for granted, by reference to standards that are independent from their particular positions or interests. ${ }^{51}$

International law, both of a primary and secondary nature, is used by protagonists in this manner - its function is rudimentary - allowing protagonists to continue the 'search for something beyond particular interests and identity politics, or the irreducibility of difference ${ }^{\prime 52}$ Such a function is not predicated on notions of criminality or otherwise, although states may occasionally deploy such accusations, particularly when faced with intransigent behaviour. As stated by Kimberly Trapp in the context of approaches to terrorism, state responsibility is not focused on retribution or punishment, it concentrates on restoration of the relations between the wronged state and the responsible state,

\footnotetext{
${ }^{48}$ La Rosa and Philippe, Transitional Justice', 368; D. Shelton, Remedies in International Human Rights Law, $2^{\text {nd }}$ edn (Oxford University Press, 2005), pp. 12-15.

${ }^{49}$ Crawford states that "there is little or no state practice to support "punitive" or "penal" consequences for breaches of international law' J. Crawford, State Responsibility: The General Part (Cambridge University Press, 2013), p. 52.

${ }^{50}$ Koskenniemi, The Gentle Civilizer of Nations, p. 501.

51 lbid.

52 Ibid., p. 500.
} 
a rationale that must be even stronger in situations where both states are wronged and wrongdoers (as if often the case in intractable long running disputes)..$^{53}$ For example, in the case of the Cuban-US dispute there is the uncompensated seizure of US property by the Cuban government in 1960 on the one hand, and the prolonged and punitive embargo imposed by the US on Cuba starting in the same year on the other.

As stated by Kimberly Trapp, the law on state responsibility 'seeks to re-establish the primary legal relationship between states as a necessary element of their peaceful co-existence' ${ }^{54}$ Furthermore, Trapp states that: the 'possibility of punitive measures imposed on a wrongdoing state does not sit comfortably within an international legal paradigm built on the sovereign equality of states, and was rejected by the ILC in its consideration of a regime of criminal responsibility for states'. ${ }^{55}$ Trapp points out that in the area of state-sponsored terrorism, the restoration of normal relations between two states (for example, between Libya and the UK as regards the Lockerbie bombing of 1988) can involve the acceptance of state responsibility by the state sponsoring terrorism, as well as measures taken to ascertain the criminal responsibility of individuals involved in terrorism. The latter was illustrated in the UK-Libya dispute by the agreement of the two countries to the trial of the two Libyan agents suspected of the Lockerbie bombing before a Scottish constituted court situated in the Netherlands in 2000-1.

If the restoration of friendly relations is combined with an understanding of peaceful settlement between states, one that combines peace and justice, then it is not necessary to stretch modern mechanisms of transitional justice, such as truth and reconciliation commissions, that have developed within post-conflict states to apply them, by analogy, to disputes between states. Nonetheless, it is helpful to keep in mind the development of transitional justice as its underpinnings are more immediately transparent than traditional modes of dispute settlement. ${ }^{56}$ By delving deeper into the traditional methods, however, it will be seen that, for example, commissions of inquiry can play a similar role to truth and reconciliation commissions in the context of bilateral disputes between states. The principles of peace and justice underpinning transitional justice are revealed to be the same as those that underpin international law.

\footnotetext{
${ }^{53}$ K. Trapp, State Responsibility for International Terrorism (Oxford University Press, 2011), p. 263.

54 Ibid.

55 Ibid.

${ }^{56}$ See, for example, R.G. Teitel, Transitional Justice (Oxford University Press, 2000) pp. 69-94; W. Lambourne, 'Tranformative Justice, Reconciliation and Peacebuilding' in S. Buckley-Zistel, T.K. Beck, C. Braun and F. Mieth (eds), Transitional Justice Theories (Abingdon: Routledge, 2014), p. 19.
} 
The principles of transitional justice provide inspiration for any modern peace process, whether internal or international, since they are founded upon achieving both peace and justice. While the traditional methods of dispute settlement applicable to inter-state disputes are normally characterised as being concerned with the attainment of peace, a deeper analysis of the more successful processes reveals that they have a concern for justice as well. Traditional methods of dispute settlement facilitate a reciprocal exchange of rights and duties between the parties as well as a restoration of normal relations between sovereign states based on mutual respect and cooperation. Both theories of transitional justice and state responsibility point to restoration rather than retribution as the guiding principle. This has implications for the peace process and the mechanisms established by it, in particular, that any judicial element of the peace process, which apportions blame or punishes violators, must be balanced by non-judicial means aimed at restoration and remediation. Judicial mechanisms, by themselves, will not bring peace.

Christine Gray makes the point that the International Court of Justice is an acceptable forum for the settlement of maritime and land boundary disputes, where the impact of its decision is mitigated by its tendency to rely on principles of equity and by the fact that both parties are looking for a genuine solution to a lack of clarity as to where the boundary between them lies. However, such limited conditions are absent in complex disputes, where political and legal disagreements are far too deep for a rules-based decision of the court, even one infused with equity. Gray questions the value of 'propaganda' type cases, such as the Tehran Hostages Case of 1980 brought by the US against Iran and the Nicaragua Case 1986 brought by Nicaragua against the US, ${ }^{57}$ in which the respondent state resists both the jurisdiction and judgment of the International Court. These cases might help to develop international law in controversial areas, but they do little to settle the dispute between the states. $^{58}$

Similar limitations are revealed in ad hoc judicial bodies, for example, the Iran-US Claims Tribunal. Despite its successes, the underlying tensions and confrontation between the two countries have not been resolved, showing that a broader approach to dispute settlement will be necessary if success is to be achieved. ${ }^{59}$ The Iran-US Claims Tribunal was created in a politically difficult and unfavourable

\footnotetext{
${ }^{57}$ US Diplomatic and Consular Staff in Tehran, (1980) ICJ Rep 3; Military and Paramilitary Activities in and Against Nicaragua, (1986) ICJ Rep 14.

${ }^{58} \mathrm{C}$. Gray. 'The Use and Abuse of the International Court of Justice in the Enforcement of International Law' in K. Koufa (ed), International Law Enforcement: New Tendencies (Athens: Sakkoulas, 2010), p. 195 at p. 198, p. 202.

${ }^{59}$ On the 2015 nuclear deal with Iran that has led to a thawing in Iranian-US relations, see M. Fitzpatrick, 'Iran: A Good Deal', Survival, 57 (2015), 47.
} 
environment after the revolution in Iran had 'deeply disturbed the relationship between Iran and the US at the end of the $1970 s^{\prime} .{ }^{60}$ Parallels with the Cuban revolution and expropriations of US-owned property and assets in 1959-60 can be seen. It is true to say that the Iran-US Claims Tribunal has become an 'exceptional arbitration mechanism' rich in jurisprudence on state responsibility for expropriations. ${ }^{61}$ In many ways it was a successor to the mixed claims commissions established at the beginning of the twentieth century, although it more clearly gave individuals access to justice by enabling complainants to file claims directly, rather than relying on their national states exercising diplomatic protection on their behalf. ${ }^{62}$ However, there is little evidence that the Iran-US Claims Tribunal has helped with reconciliation between the US and Iran, whose relationship has remained one of confrontation up to the level of threats of force and limited uses of force. ${ }^{63}$ Indeed, in 1981 the Iran-US Claims Tribunal came to a decision (by majority) that Article II of the claims settlement declaration did not include a right for Iran to bring claims against US nationals on the grounds that a 'clear formulation' of that provision excluded Iranian claims from the jurisdiction of the Tribunal. Although the majority could draw support for this interpretation from a textual reading of the Article, the minority pointed out that this undermined any reciprocity underpinning the agreement. ${ }^{64} \mathrm{By}$ disregarding that reciprocity, the Tribunal has provided only one-sided justice and, although that is some justice, it is not one upon which to build reconciliation and restoration between the two countries.

\section{Towards a peace agreement}

In the field of complex dispute settlement international law works as part of a political process, rather than as part of a judicial-type process based on the attempted application of rules to provide blackand-white solutions and answers. The indeterminacy at the heart of international law signifies that a purely formalist approach is at worse a deception, at best a genuine, but flawed, attempt at syllogistic reasoning. In contrast, Koskenniemi's 'culture of formalism' is based on a conception of universality that is 'neither a fixed principle nor a process but a horizon of possibility that opens up the particular

\footnotetext{
${ }^{60}$ D. Muller, 'Other Specific Regimes of Responsibility: The Iran-US Claims Tribunal' in J. Crawford, A. Pellet and S. Olleson (eds), The Law of International Responsibility (Cambridge University Press, 2010), p. 843.

${ }^{61} \mathrm{lbid}$.

${ }^{62}$ Muller, 'Other Specific Regimes of Responsibility', pp. 844-5.

${ }^{63}$ See Oil Platforms (Islamic Republic of Iran v United States of America), (2003) ICJ Rep 161. In 2010 there was an unattributed cyber-attack using Stuxnet against Iran's nuclear plants resulting in the destruction of centrifuges essential for the enrichment of uranium.

${ }^{64}$ Iran-US Claims Tribunal, Interpretation of the Algerian Declaration of $19^{\text {th }}$ January 1981, International Law Reports, 62 (1982), 599-600.
} 
identities in the very process where they make their claims of identity'. ${ }^{65}$ Dispute settlement is driven by political interests and compromises, but it is argued that the most legitimate agreement, and, therefore, those having the best chance of longer-term success emerging from a peace process, are those framed by international law and, indeed, key principles of international law provide the basis for agreement. The International Court of Justice may be a suitable forum for specifically (and narrowly) defined disputes, but it is no match for diplomacy and associated non-judicial methods when complex disputes are being addressed. This does not mean that international law is irrelevant, but what it does mean is that we have to think about international law in terms of revealing a 'horizon of possibilities' for negotiators, in contrast with negotiations that are simply framed by politics, which will result in a 'clash of incommensurate "value systems" none of which can be rationally preferred'. ${ }^{66}$

The importance of diplomacy was made clear by the International Court of Justice in a 1980 case concerning US hostages being held in Iran, another facet of the confrontation between the US and Iran. The Court described diplomacy as an instrument essential for effective cooperation in the international community, and for enabling states, irrespective of their differing constitutional and social systems, to achieve mutual understanding and to resolve their differences by peaceful means' ${ }^{67}$ Bearing in mind the importance of diplomacy establishing a basis of reciprocity in order to achieve restoration of normal relations between states involved in a bilateral dispute, the chapter now turns to the methods of dispute settlement normally deployed in international law and relations. It will be seen that these methods are a practical application of what Koskenniemi has called the need to achieve an 'equitable balance' in resolving disputes. ${ }^{68}$

The whole process of negotiation towards an agreement with reciprocal rights and duties is premised on the obligation to settle disputes peacefully, which is a basic principle of international law as located in the UN Charter. ${ }^{69}$ Furthermore, the purposes of the UN Charter prominently include the admonition to 'bring about by peaceful means, and in conformity with the principles of justice and international law, adjustment or settlement of international disputes or situations which might lead to a breach of the peace' ${ }^{70}$ It is that combination of justice and law that facilitates an equitable interpretation and application of legal principles within a new or emerging political context. ${ }^{71}$

\footnotetext{
65 Koskenniemi, The Gentle Civilizer of Nations, p. 506.

66 Ibid., pp. 505-6.

67 Tehran Hostages Case, (1980) ICJ Rep 3 at 91.

${ }^{68}$ Koskenniemi, 'The Politics of International Law', 14.

${ }^{69}$ Article 2(3), UN Charter 1945.

${ }^{70}$ Article 1(1), UN Charter 1945, emphasis added.

${ }^{71}$ Koskenniemi, 'The Politics of International Law', 14.
} 
Chapter VI of the UN Charter, which covers the peaceful settlement of disputes, obligates disputant states to 'seek a solution by negotiation, enquiry, mediation, conciliation, arbitration, judicial settlement, resort to regional agencies or arrangements, or other peaceful means of their own choice', before resorting to the Security Council. ${ }^{72}$ These methods of settlement are not necessarily mutually exclusive. All settlement processes commence with negotiation and, in relatively confined issues, this may be sufficient to produce agreement. ${ }^{73}$ In relation to intractable disputes, an unwillingness by the parties to meet face-to-face, or the lack of progress in 'talks about talks', might lead the parties to allow for third party intervention in the settlement process. At one end of a spectrum third party involvement may simply take the form of 'good offices' or a 'channel for communication', while the other end involves the 'assignment' to the third party or body 'to investigate the dispute and to present the parties with a set of formal proposals for its solution'. The latter is known as 'conciliation', whereas 'mediation' is situated somewhere between good offices and conciliation. ${ }^{74}$ The mediator is an 'active participant authorised, and indeed expected, to advance fresh proposals and to interpret as well as transmit, each party's proposals to the other'. ${ }^{75}$

Given the historical animosity between the parties in the disputes mentioned at the outset of this chapter, mediation may represent a suitable method rather than to face-to-face negotiations, also bearing in mind that neither government of the disputant states would necessarily want to be faced with a concrete set of proposals for peaceful settlement coming from a conciliation commission. Mediation accords with the idea of a settlement process that operates within an equitable framework of law and justice, underpinned by reciprocity and aiming for restoration. Ultimately, it is up to both parties to agree on a mediator. John Merrills asks:

What of the mediator's substantive contribution? The aim ... must be to satisfy both parties. In some situations it will be possible to do this by giving each state all or most of what it wants. This is because the aims of the parties in an international dispute are rarely identical and often quite different. Of course, the fact that there is a dispute indicates that the parties' aims are not entirely compatible, but unsuccessful negotiations may cause these differences to become the exclusive focus of attention. A mediator who can remind the parties of their essential objectives (or cause them to be redefined) may therefore be in a position to suggest a mutually satisfactory arrangement. ${ }^{76}$

Alternatively, or possibly in addition, the parties might be encouraged to agree on another traditional method of inter-state dispute settlement - inquiry. Inquiry involves bringing in a third party or body

\footnotetext{
72 Article 33(1) UN Charter 1945. See also Article 25 OAS Charter.

73 J.G. Merrills, International Dispute Settlement, $5^{\text {th }}$ edn (Cambridge University Press, 2011), pp. 22-5.

74 Ibid., p. 26.

75 Ibid.

76 Ibid., p. 35.
} 
to 'provide the parties with an objective assessment' ${ }^{77}$ Traditional inquiries have, on occasions, gone beyond providing an independent assessment of the facts underlying or leading to the dispute and have made recommendations towards settlement of the dispute and reconciliation of the parties. For example, the Dogger Bank Inquiry of 1904-5, consisting of admirals from the UK, Russia, France, US and Austro-Hungary, was established to report on the circumstances and issues of responsibility and blame surrounding the damage done to the Hull trawler fleet by the Russian navy in the North Sea. The Inquiry's report helped to avoid conflict and normalise relations between the UK and Russia. ${ }^{78}$

\section{Finding common (legal) ground}

Most of the disputes mentioned at the outset of this chapter involve issues of territory, sovereignty, self-determination (political and economic), and may also extend to human rights (socio-economic as well as civil-political). Disagreements on their meaning and application continue to fuel the dispute, for example, in the Cuba-US dispute, between the self-determination of the Cuban people based on independence from outside domination (as argued by the Cuban government) and self-determination based on free expression of the people in multi-party elections (as argued for by the US). For example, in the UN Human Rights Universal Periodic Review of Cuba in 2013, the Cuban representative pointed to the 'relentless attempts by the United States to impose a regime of change on the Cuban people', which was a 'serious violation of its right to self-determination' ${ }^{79}$ The US understanding of selfdetermination is made clear in the wording Helms-Burton Act of 1996, which embodied the longstanding embargo in legislation and, in so doing, stated that the purpose of continuing and tightening the embargo was 'to encourage the Cuban people to empower themselves with a government which reflects the self-determination of the Cuban people' and, further, 'to facilitate the rapid movement from such a transitional government to a democratically elected government in Cuba that results from an expression of the self-determination of the Cuban people' ${ }^{\prime}{ }^{80}$

Disagreements on the fundamental principles of international law represent the core of disputes and, therefore, they inevitably will form the general framework for any dispute settlement process. The aim of any peace process will be for those states involved to achieve common understandings on such principles in the context of the bilateral relationship between them. The genuine consent of the two

\footnotetext{
77 lbid., pp. 41.

78 Ibid., pp. 42-3.

79 Human Rights Council, Report of the Working Group on the Universal Periodic Review: Cuba, UN Doc A/HRC/24/16 (2013), paras 5-6.

${ }^{80}$ Cuban Liberty and Democratic Solidarity (Libertad) Act 1996, Title II, Section 201 (P.L. 104-114).
} 
states in achieving any such agreement will reconcile the common understanding of the two states in the concrete dispute between them with general principles of international law in their abstract form, unless any agreement is clearly in conflict with a norm of jus cogens.

According to the Articles on State Responsibility of 2001, consent cannot be used as an excuse for a peace agreement adopted in violation of a norm of jus cogens.$^{81}$ This principle is also contained in the Vienna Convention on the Law of Treaties 1969, to the effect that any peace treaty adopted in violation of a peremptory norm of international law will be seen as null and void. ${ }^{82}$ Alexander Orakhelashvili has demonstrated that self-determination is a peremptory norm of international law accepted by the international community as allowing no derogation..$^{83}$ However, this has to be placed within the context of the indeterminacy that haunts the principle of self-determination in international law, in both its political and economic aspects, allowing states a significant degree of room to negotiate as to how it will be protected and implemented. As Rein Mullerson points out in relation to another norm of jus cogens - the prohibition on the use of force - while states agree that the prohibition is jus cogens, they are not agreed on its precise content or the content of the exceptions to it. ${ }^{84}$ More generally, it has been accurately stated that 'one of the criticisms of jus cogens is that they lack sufficiently robust meaning to provide effective constraints on decision making' ${ }^{85}$

Finding common legal ground involves a recognition that international laws often do not give black and white answers, for example, as to whether sovereignty is absolute or mediated, ${ }^{86}$ whether nonintervention covers all forms of interference, whether self-determination is a purely external one-off event or whether it is internal on-going process (and the meaning of this), and whether civil and political rights have priority over socio-economic rights. ${ }^{87}$ Such uncertainty signifies that alternative choices can be made by states and a variety of contextual understandings agreed upon. It follows that while legal principles frame discussions, they cannot determine the dispute without common agreement on their meaning and application in the context of the political relationship between the two states, as well as the broader geopolitical context. Drawing upon the works of Jurgen Habermas,

\footnotetext{
${ }^{81}$ Articles 20 and 26, Articles on the Responsibility of States for Internationally Wrongful Acts 2001.

${ }^{82}$ Article 53, Vienna Convention on the Law of Treaties 1969.

${ }^{83}$ A. Orakhelashvili, Peremptory Norms in International Law (Oxford University Press, 2006), pp. 51-3.

${ }^{84}$ R. Mullerson, 'Jus Ad Bellum: Plus Ca Change (Le Monde) Plus C'est La Meme Chose (Le Droit)?', Journal of Conflict and Security Law, 7 (2002), 149.

85 M. Del Mar, 'System Values and Understanding Legal Language', Leiden Journal of International Law, 21 (2008), 29 at 58.

${ }^{86}$ M. Perez-Stable, The Cuban Revolution: Origins, Course, and Legacy, $2^{\text {nd }}$ edn (Oxford University Press, 1999) p. 37.

${ }^{87}$ M. Koskenniemi, From Apology to Utopia (Helsinki: Finnish Lawyers' Publishing Co, 1989), p. 67, where he states that 'international law is singularly useless as a means for justifying or criticising behaviour'.
} 
Steven Wheatley depicts such an approach as one of 'deliberative diplomacy', ${ }^{88}$ where the aim is to establish a 'communicative consensus' about the parties' 'understanding of a situation as well as justifications for the principles and norms guiding their actions' ${ }^{89}$ Parties refer to a common system of norms and rules, ${ }^{90}$ with international law supplying the 'rules of the game' ${ }^{91}$ This signifies that 'once international relations are framed in terms of law, they operate within the disciplinary constraints of an interpretive community'..$^{92}$ Legal discourse involves 'appeals to legal norms as they are understood not by each actor individually (subjectively) or in some abstract sense (objectively) but together as a collective law-interpreting body (inter-subjectively)' ${ }^{93}$ While powerful states have greater leverage within diplomatic relations, they 'cannot change those rules (and shift the terms of the debate) instantaneously and at will'. ${ }^{94}$ Powerful states have to respect the 'conventions of argument, persuasion and justification associated with the particular enterprise in which the deliberations occur' ${ }^{95}$ However, given the problems of indeterminacy in a number of applicable principles and rules of international law, there is scope for 'divergent legal arguments'. ${ }^{96}$

In effect, international law operates as the common language for diplomacy, not as a system of readily applicable rules. This allows the parties to achieve understanding upon which a peaceful solution can be built, building on Koskenniemi's idea that when the political relationship governing two states comes to an end international law operates to fill in the space vacated by politics, but it does not do so by providing a ready solution or answer. Furthermore, while indeterminacy takes away the legs from a purely formalist approach to international law, Koskenniemi's critique reveals that a 'culture of formalism' whereby, 'although every (legal) decision is constitutive, and not just a reproduction of some underlying structure, each decision also acts as a kind of surface on which the horizon of universality becomes visible'. ${ }^{97}$ Thus, while 'indeterminacy provides cope for divergent legal arguments', ${ }^{98}$ it 'does not render discourse meaningless' ${ }^{99}$ International legal principles applicable to

\footnotetext{
${ }^{88}$ S. Wheatley, The Democratic Legitimacy of International Law (Oxford: Hart, 2010), p. 138.

89 T. Risse, "'Let's Argue": Communicative Action in World Politics' (2000) 54 International Organization, 54 (2000), 1 at 9.

90 lbid., at 10.

91 J. Habermas, 'Does the Constitutionalization of International Law Still Have a Chance?' in C. Cronin (ed), The Divided West (Cambridge: Polity, 2006), p. 115 at p. 119.

92 Wheatley, The Democratic Legitimacy, p. 143.

93 I. Johnstone, 'The Plea of "Necessity" in International Law Discourse: Humanitarian Intervention and CounterTerrorism', Columbia Journal of Transnational Law, 43 (2005), 337 at 381.

94 Ibid., 383.

95 Ibid.

${ }^{96}$ Wheatley, The Democratic Legitimacy, p. 149.

${ }^{97}$ Koskenniemi, The Gentle Civilizer of Nations, p. 508.

98 Wheatley, The Democratic Legitimacy, p. 149.

99 S. Toope, 'Emerging Patterns of Governance and International Law' in M. Byers (ed), The Role of Law in International Politics (Oxford: Oxford University Press, 2000), p. 91 at p. 102.
} 
the dispute, indeed often at its heart, must be discussed, interpreted, agreed upon in formal or informal terms and, finally, implemented. If common ground has been successfully captured in that agreement, subsequent political relations can be framed by international law as encapsulated in the agreement.

The flexibility contained within the primary rules of international law, facilitating choice and agreement by the parties to an inter-state dispute, is matched by the secondary rules of international law. Although the 'rules' on state responsibility may appear to be rigid and formal, these rules are constructed in such a way that enable them to be shaped and applied by states in order to facilitate the settlement of disputes between them. All state disputes, and indeed any situation where a state is responsible for breach of the primary rules of international law, are governed by the Articles on State Responsibility of 2001, which, for instance, provide that 'full reparation for the injury caused by the internationally wrongful act shall take the form of restitution, compensation and satisfaction, either singly or in combination'. ${ }^{100}$ The Articles also provide that the 'state responsible for an internationally wrongful act is under an obligation to give satisfaction for the injury caused by that act insofar as it cannot be made good by restitution or compensation' and that 'satisfaction may consist in an acknowledgement of the breach, an expression of regret, a formal apology or another appropriate modality'. ${ }^{101}$ The point is that even under the apparently formal rules of state responsibility there is a range of remedies that can be adjusted as appropriate to the dispute under consideration. States involved in a complex dispute, in which both sides have violated international law, may have to concede that remedies will be available against them if settlement is to be achieved. In this way the secondary rules of responsibility fit the notion that international law provides a framework within which states can settle their disputes. As recognised by Martii Koskenniemi, in the practical world of dispute settlement the 'applicable rules come about through a complex diplomatic play that aims at freedom and constraint simultaneously'. ${ }^{102}$

It should be borne in mind that the secondary rules on state responsibility, as found in the ILC's Articles of 2001 , should not be seen as a form of international legislation, to be applied by courts and other bodies without regards to practice and context. They are abstract principles that require shaping and re-shaping by states within particular contexts to provide them with tools of international law with which they can normalise their international relations with other states after a rupture between them involving violations of international law. To view the Articles on State Responsibility as an inflexible

\footnotetext{
${ }^{100}$ Article 34, Articles on the Responsibility of States for Internationally Wrongful Acts 2001.

${ }^{101}$ Article 37, ibid.

${ }_{102}$ M. Koskenniemi, 'Doctrines of State Responsibility' in Crawford, Pellet and Olleson (eds), The Law of International Responsibility, p. 45 at p. 51.
} 
set of rules would be a mistake. They are not constructed in such a way. The very fact that the ILC's Articles did not take the form of a treaty, but are left as soft laws to be developed by interpretation and application to disputes, implies that they are meant to be adapted and shaped by state practice.

\section{Conclusion}

It has been argued in this chapter that the parties to those disputes outlined in the introduction will, at a certain critical point in the future, seize the moment when there is a dramatic break in the political context that has governed their relations, thereby setting off a process of diplomacy whereby the parties, through discussion of general issues and specific mechanisms, move towards a peace agreement in which the parties agree to normalise their diplomatic, political and economic relations over a period of time. The peace process and peace agreement in inter-state disputes is primarily aimed at restoring and normalising peaceful relations between the parties. However, it has been shown in this chapter that the concept of 'restoration' is not just embodied in modern notions of transitional justice, as applied within conflict-ridden states, but is also found within the primary and secondary rules of international law and mechanisms that are applicable to states in their inter-state relations to provide for accountability for breach of those rules.

The indeterminacy of the primary and secondary rules of international law, as unveiled by Martii Koskenniemi particularly in his earlier work, ${ }^{103}$ enables the parties to negotiate a common understanding of them in the context of their dispute and the political conditions between them. Koskenniemi makes it clear that his characterisation of indeterminacy is not that all international legal terms are 'semantically ambivalent', but is a much stronger claim that 'even where there is no semantic ambivalence whatsoever, international law remains indeterminate because it is based on contradictory premises', for example, as to whether sovereignty entails freedom or responsibility, or whether self-defence contains within it an element of anticipation and, if so, how much. ${ }^{104}$ Nonetheless, Koskenniemi's message is a positive one - that such inherent indeterminacy is not to be seen as a 'structural deficiency', but as an 'absolutely central aspect of international law's acceptability'. ${ }^{105}$ In this sense, the weakness of international law, so pointedly identified by

\footnotetext{
${ }^{103}$ Koskenniemi, From Apology to Utopia, p. 67.

${ }^{104}$ See his 2005 epilogue to his original work in M. Koskenniemi, From Apology to Utopia: The Structure of International Legal Argument (Cambridge: Cambridge University Press, 2006), pp. 590-1.

105 Ibid., p. 591.
} 
Koskenniemi, can also be a strength if its role as a 'gentle civilizer', developed by Koskenniemi in his later works, ${ }^{106}$ is properly recognised and allowed to function and flourish within political processes.

Indeed, all of Koskenniemi's work is united by a recognition that international law appears as a rigorous form of formalism while, at the same time, being simultaneously politically open-ended. ${ }^{107}$ The key to understanding international law is to resist the "pull of either excessive "formalism" or excessive policy-oriented "realism"', ${ }^{108}$ and to see it primarily 'as a language of justification'. ${ }^{109}$ This means that international law is a 'means to articulate particular preferences or positions in a formal fashion', which will reveal the 'possibilities and limits of political contestation through the adoption of a culture of formalism in a particular institutional environment' ${ }^{110}$ Justifications and arguments are made not in the abstract but in relation to concrete cases so that, for example, "'sovereignty" cannot be grasped by examining the "idea of sovereignty" somehow floating autonomously in conceptual space but by studying how that word is invoked in institutional contexts so as to make or oppose particular claims' ${ }^{111}$ For Koskenniemi, this signifies that the 'grammar of sovereignty shifts between assuming the full rights of States (concrete) and their complete submission to a binding law (normative)' and, furthermore, that 'closure is attained by balancing formulas' such as 'reasonable' or 'equitable', or 'simply by agreeing to seek agreement in a local or otherwise situation-specific context'. ${ }^{112}$ While this chapter has argued for the profound relevance of such an approach in a bilateral inter-state dispute, it has also adopted the position that any such local agreement coming out of the process will not only embody particularities, but will contain agreement on contested terms of international law such as 'sovereignty' and 'self-determination', meaning that international law can provide the basis for a meeting of the minds. The peace agreement will also include compromises based on the equitable sharing of resources, liabilities and assets. However, those compromises flow from inter-subjective agreement between the parties on disputed legal principles and that, following Koskenniemi, those formalistic legal arguments adopted by the parties represent their political preferences.

The approach outlined in this chapter, influenced by the thinking of Martii Koskenniemi, is compatible with the process of 'deliberative diplomacy' identified by Habermas and Wheatley and, furthermore, is also resonant with the work of Christine Bell, a leading exponent of the law of peace and peace

\footnotetext{
${ }^{106}$ Koskenniemi, The Gentle Civilizer of Nations, p. 515.

107 Koskenniemi, From Apology to Utopia (2006), p. 563.

108 Ibid., p. 564.

109 lbid., p. 570.

110 lbid., p. 571.

111 Ibid., p. 572.

112 Ibid., p. 583.
} 
agreements. Bell examines a number of peace agreements in detail (the Oslo Accords of 1993 containing the Israel-Palestinian Declaration of Principles, the Agreement on the Constitution of South Africa of 1993, the Dayton Accords on Bosnia of 1995 and the Good Friday Agreement of 1998 for Northern Ireland). While recognising the deficiencies of these agreements (particularly, though not exclusively, the failure to fully deliver the Palestinians' right to self-determination, the lack of accountability for past atrocities in Northern Ireland, the failure to fully address the embedded nature of inequalities in South Africa, and the paternalistic interventionist nature of Dayton), Bell's conclusion on the role of law in peace agreements is largely in line with the argument and analysis found in this chapter:

As regards international law, while its traditional regulative function may seem particularly susceptible to political vagaries, this observation is not new. However, the facilitative impact of a broad range of soft and hard law standards indicates a greater role for international law than might have been imagined, and a need for international law to rise to the occasion. Politicians agreeing to human rights measures in the heat of negotiations often draw on international standards. Continued evolution of the facilitative function of international law does not necessarily depend upon a hardening of the law, but more on international law remaining creatively connected to notion of 'good practice' and capable of commanding a moral normativity. ${ }^{113}$

The argument in this chapter is a simple one: that, while acknowledging the indeterminacy of key principles of international law, it is possible to apply the approach Bell outlines to inter-state disputes, even apparently intractable ones, drawing on those strengths underpinning the primary and secondary rules of international law - of mutual respect, peaceful co-existence and reciprocity - to achieve a restoration and normalisation of international relations.

This chapter has placed dispute settlement broadly within Koskenniemi's indeterminacy thesis and then adapted Koskenniemi's idea of international law as the 'gentle civilizer of nations', which he posited generally in the form of a question: 'between the arrogance of universality and the indifferences of particularity, what else is there apart from the civilized manner of gentle spirits?'114 After showing how Koskenniemi's analysis of law can play a role in relation to collective security, this chapter applied such thinking to bilateral disputes. In so doing, the chapter has demonstrated that such disputes will not be resolved by the 'indifferences of particularity' but, drawing on Koskenniemi's ideas, it has shown that when the political regime encasing the dispute collapses, or radically changes, law can and should play a crucial role in establishing a new political regime based on the normalisation of relations.

\footnotetext{
${ }^{113}$ C. Bell, Peace Agreements and Human Rights (Oxford University Press, 2000), pp. 320-1.

${ }^{114}$ Koskenniemi, The Gentle Civilizer of Nations, p. 515.
} 